\title{
Editoria
}

\section{Memorial of Professor Zdeněk Pouba (1922-2011)}

\section{Zdeněk PERTOLD}

\begin{abstract}
Institute of Geochemistry, Mineralogy and Mineral Resources, Charles University, 12843 Prague 2, Czech Republic; zdenek.pertold@natur.cuni.cz
\end{abstract}

Received: 30 October 2012; accepted: 30 September 2013; handling editor: D. Dolejs

The online version of this article (doi: 10.3190/jgeosci.151) contains supplementary electronic material.

Zdeněk Pouba, professor emeritus of mineral deposits, Charles University Prague, passed away peacefully in his home on December 27, 2011 at the age of 89 . He was an outstanding teacher, a leading personality of the Czechoslovak and, later, Czech geology, particularly of mineral deposits. With wide international connections, he was one of the co-founders of IAGOD (International Association on Genesis of Ore Deposits) in 1963, in an attempt to overcome the information gap and to renew personal contacts across the iron curtain. By these efforts he collaborated with many scientists on both sides, e.g., C. F. Davidson, C. F. Park, V. I. Smirnov, P. Zuffardi, W. Uytenbogaardt, J. Minceva-Stefanova and many others, and with J. Kutina and M. Štemprok in Prague, to mention only a few of them.

Zdeněk Pouba also became active in the newly formed SGA (Society for Geology Applied to Ore Deposits) when the communist pressure softened in Czechoslovakia in the sixties. Together with A. Bernard in Nancy, they organized exchange trips with teachers and students. Prof. Pouba took the first opportunity to initiate co-operation of Charles University with Gunnar Kautsky from the Geological Survey of Sweden. Zdeněk Pouba was the vice-president of the International Geological Congress in Prague in 1968, preparing the mineral deposit section and the stratiform deposit field trips together with H. Gruszczyk in Krakow. Stratiform deposits had been Pouba's topic for many years after that time. Together with a local team of colleagues, he edited eight volumes of Correlation of Proterozoic and Palaeozoic Stratiform Deposits, became involved in the IGCP and organized sessions in Czechoslovakia (e.g., Metallogeny of the Precambrian).

Being an excellent teacher and speaker with wide geological interests, Professor Pouba wrote the textbook "Geological mapping" (1959, in Czech), in which he combined and summarized the results of Kettner's Prague school, Andrusov's school in the Carpathians and his own experience. In 1963-1970 he became a member of the Commission for Geology Teaching at the University

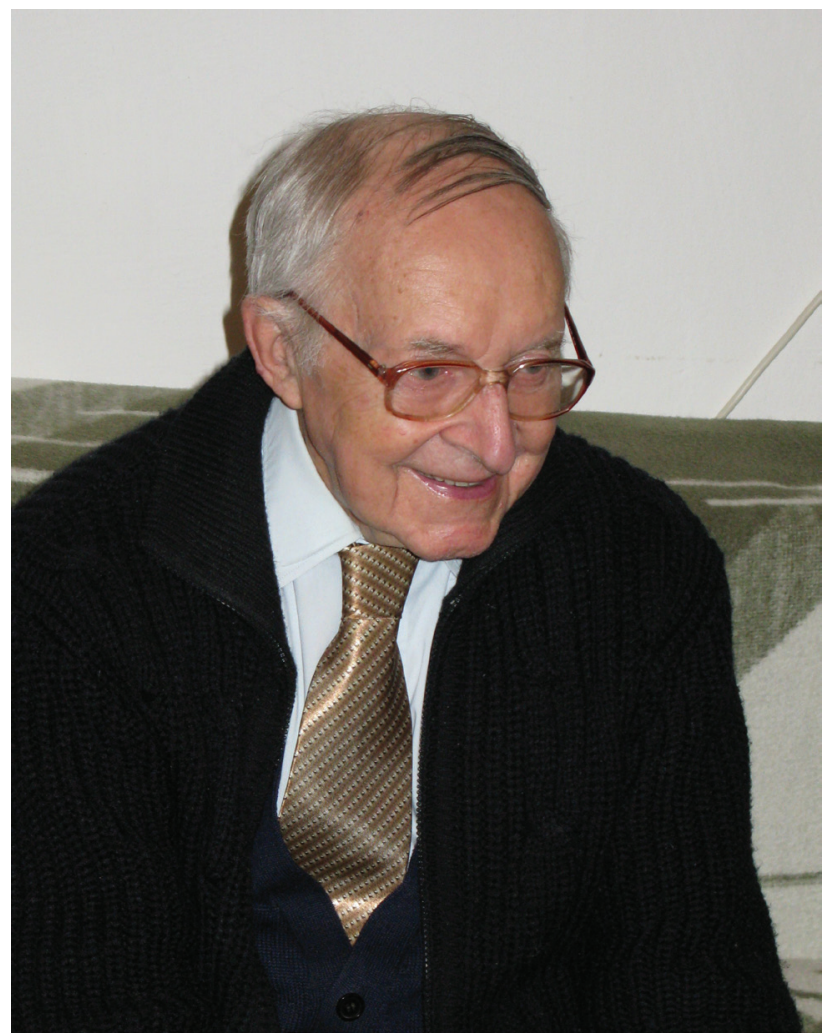

Level of IUGS (a predecessor of today's IUGS Commission on Geoscience Education, Training and Technology Transfer) with one of its meetings in Prague. He never hesitated to exploit the opportunity to become a student again as, for instance, in G. Kullerud's course on sulphide equilibria at the Carnegie Institution of Washington.

Developing idea of Professor J. Koutek to organize underground geological mapping courses, Professor Pouba introduced them into the curriculum in 1954, and either organized or took part in more than forty of them. Zdeněk Pouba's knowledge of regional and local geology, his appreciation of local communities (most courses in the Carpathians), his friendly personality combined with his sense of humor, tales and narrations, his guitar, Slo- 
vak, Czech, miners' and trappers' songs, all this has had lasting impact on the participants, often with guests from distant countries, like Prof. C. Naganna from Bangalore or T. Nakamura from Osaka.

It was Professor Pouba's policy to invite people from abroad to the Department when the possibilities to travel were limited for us, especially after 1970. His co-operation with A. Evans resulted in student exchange field trips with Leicester University. David H. Watkinson from Carleton University became a frequent guest and speaker in our Department. He and his friends, especially George B. Skippen and Ian Jonasson with students arrived in Czechoslovakia for a field trip in the difficult year of 1978. Zdeněk Pouba succeeded in getting permissions for a staff and student field trip to Canada the next year, when our Carleton friends made special efforts to raise funds and organized a two-week excursion to famous mineral deposits in Quebec and Ontario. David Watkinson and Zdeněk Pouba became friends and stayed in contact to the very end.

Looking at the list of Pouba's publications, the reader can appreciate that his scope of interests was very wide. From regional geology to base-metal, magnetite, kaolin and gold deposits, their ore-forming processes and sources, from general and structural geology to volcanism, from metallogeny to mining overviews and problems related to research policy. Exceptionally, paleontology was also a by-product of his geological interests: in his first research paper (1947) he described a new Bryozoan from the Bohemian Ordovician. In 1973, Zdeněk Pouba discovered stromatolites in the Neoproterozoic cherts of the Barrandian and published several papers on this topic. $\mathrm{He}$ and his team summarized their results on Neoproterozoic sediments, volcanics and ores in the Barrandian area in the Bulletin of the Czech Geological Survey, vol. 75 in 2000, where Pouba's last research papers appeared.

Born in Zvolen, Slovakia, to Czech parents (his father was an official in the newly formed National Railways), he was a typical representative of new Czechoslovak generation. He attended Slovak elementary school and six grades of secondary school. He became excited about the nature of the Central Slovakian volcanics, discovering it with a Woodcraft group, and was deeply influenced by E. T. Seton, whom he met briefly during his visit to Czechoslovakia. His family moved to Prague after the German occupation, where he finished his college studies. Forced to work in an airplane factory, he experienced the end of the World War II as a Boy Scout messenger and a member of the first aid unit in the Prague uprising in May 1945.

The summer semester of 1945 was the beginning of his university studies, as for many other people of his generation, immediately after the Czech universities re-opened. Zdeněk Pouba became a student and soon was promoted to assistant to Professor R. Kettner, who was the leader of modern Czech geology. When Professor Kettner founded mineral deposit division in his Geological Institute and invited Professor Koutek to organize and chair it, Pouba became his assistant. After J. Koutek suffered a serious health problem, Pouba was appointed head of the new Department of Raw Materials (later Mineral Deposits) and continued in this position very successfully until the end of the seventies, when political pressures became too strong. He created an atmosphere in the department, which was open, liberal, friendly, and demanded intensive work. The team was well-known, unique and open for cooperation with other people and institutions.

Zdeněk Pouba served in many positions at the university, in many geological societies and organizations; he was a member of numerous commissions and of the Commission on Mineral Reserves for forty years. After he was appointed Professor Emeritus, he continued to participate in the departmental seminar as one of its most frequent and refreshing debaters. He also returned to Slovakia as a consultant for gold exploration together with his pre-war friend S. Krríž, graduate of the Princeton University. Zdeněk Pouba also maintained contact with the wider geological community, especially but not only, in the Barrande Club organized by V. Sattran, always ready to discuss geology, science and philosophy with an open mind and realistic views, never missing and enjoying amusing moments. Being a golfer, he found his physical and mental relaxation on fairways and greens until his final years. Zdeněk Pouba's seven children and their families, his friends and colleagues will all miss him and cherish the memory of his wonderful personality.

Electronic supplementary material. The complete bibliography of Prof. Zdeněk Pouba is available online at the Journal web site (http://dx.doi.org/10.3190/jgeosci.151).

\section{Selected bibliography of Zdeněk Pouba}

Pouba Z (1947) Nová mechovka z bohdaleckých vrstev (A new Bryozoan from the Bohdalec Shales, Bohemian Caradoc). Věst. Král. čes. Spol. Nauk, 6, 1-12. Praha

Pouba Z (1949) Geologické a petrografické problémy Vysokého Jeseníku (Geological and petrographical problems of the Vysoký Jeseník). Přírodověd. Sbor. ostrav. Kraje, 10, 2, 95-122. Opava

Pouba Z (1949) Geologický vývoj motolského údolí (The geological evolution of the Motol Valley). Sbor. Stát. geol. Úst., 16, 799-844. Praha

PouBa Z (1951) Geologie střední částí Muráňské plošiny (Geological study of the Murán Plateau). Sbor. Ústř. Úst. geol., 18, 273-306. Praha 
PouBA Z (1951) The lead-zinc ores from the northern foot of the Murán̆ Plateau (Central Slovakia). Rozpr. Čs. Akad. Věd, II. tř,, 61, 41, 1-19, Praha

Petránek J, Pouba Z (1951) Pokus o datování vývoje jeskyně Domica na základě studia tmavých zón v krápnících a sintru (Dating of the development of the Domica Cave, based on the study of the dark zones in the travertine formation). Sbor. Ústř. Úst. geol, 18, 245-273. Praha

PoubA Z (1953) Několik nových nálezů rud v mesozoických sériích u Šumiace a Švermova v Horehroní (Some new fínds of ores in the Mesozoic series at Sumiac and Švermovo in Slovakia). Sbor. Ústř. Úst. geol., 20, 193-204. Praha

Pouba Z, Špinar Z (1954) Stratigrafické poměry okolí kaolinového ložiska u Chlumčan (jižní část plzeňské pánve). Věst. Ústř. Úst. geol., 19, 145-158. Praha

HrdličKa L, PouBA Z (1955) Geofyzikální kontrola geologických profilů frekvenční odporovou metodou (Geophysical control of geological sections by the frequency resistivity method). Acta Univ. Carol., Geol., 1, 111-130. Praha

Pouba Z, Špinar Z (1955) K otázce rozššřrení terciéru v Plzeňské pánvi (On the distribution of the Tertiary in the Plzeň Basin). Věst. Ústř. Úst. geol., 30, 145-161. Praha

Pouba Z, Vejnar Z (1956) Polymetalické rudní žíly u Jasenie v Nízkých Tatrách (The polymetallic ore veins at Jasenie in the Nízké Tatry). Sbor. Ústř. Úst. geol., 22, 485-555. Praha

Koutek J, Pouba Z (1956) Přehled geologických poměrů rudního ložiska Magurka v Nízkých Tatrách (On geological conditions of the ore deposit Magurka in the Nízké Tatry). Sborník k osmdesátinám akad. F. Slavíka, Ústř. Úst. geol., 169-195. Praha

Pouba Z (1959) Geologické mapování. Čs. Akad. Věd, 1-524. Praha

Pouba Z (1959) Některé geologické zákonitosti vzniku a rozmístění nerudných surovin v Plzeňské pánvi (Einige geologische Gesetzmässigkeiten in der Entstehung und Verbreitung der Nichterze im Becken von Plzeň). Acta Univ. Carol., Geol., 3, 343-361. Praha

PoubA Z (1960) Magnetite Ores of Sydvaranger type in Czechoslovakia. Report of the Twenty-First Session, Norden, Int. Geol. Congress, Part XVI, 164-170. Copenhagen

PouBA Z (1960) Tektonická mapa ČSSR 1: 1000 000. Ústř. Úst. geol. Praha

Pouba Z IN ČEPeK L ET AL. (1960) Geologická mapa ČSSR 1 : 200000 M-33-XX Plzeň. Ústř. Úst. geol. Praha

Pouba Z in Čepex L, Zoubek V (1961) Vysvětlivky k přehledné geologické mapě ČSSR 1 :200 000 M-33XX-Plzeň (Terciér). Ústř. Úst. geol. Nakl. Čs. akad. Věd, 129-134. Praha

Pouba Z, Mísař Z (1961) O vlivu příčných zlomů na geologickou stavbu Hrubého Jeseníku (Einfluss der
Querbrüche auf den geologischen Aufbau des Hohen Gesenkes). Čas. Miner. Geol., 6, 3, 316-324. Praha

Pouba Z, ŠPINAR Z (1961) Stratigrafie a paleontologie terciérních uloženin v okolí Zruče a Žichlic (východně od Třemošné) v Plzeňské pánvi (Über die Stratigraphie und Paläontologie tertiärer Ablagerungen in der Umgebung von Zruč und Žichlice (östlich von Třemošná) im Pilsner Becken). Čas. Min. Geol., 6, 1, 59-65. Praha

PouBA Z ET AL. (1962) Vysvětlivky k přehledné geologické mapě ČSSR $1: 200000$ M-33-XVIII Jeseník. Ústř. úst. geol. Nakl. Čs. Akad. Věd, 1-178. Praha

PoubA Z (1963) Polymagmatic zoning of ore deposits on a regional scale. Symposium Problems of Postmagmatic Ore Deposition, 1, 52-57. Praha

PoubA Z ET AL. (1963) Geologická mapa ČSSR 1 : 200000 M-33-XVIII Jeseník. Ústř. Úst. geol. Praha

Pouba Z (1964) Silezikum. In: Svoboda J eT AL Regionální Geologie ČSSR I. Český masív, sv. I. Krystalinikum, 283-328. Praha

Pouba Z (1965) On some causes of the repetition of mineralization in ore regions and ore deposits of the Czech Massif. Symposium Problems or Postmagmatic Ore Deposition, 2, 82-89. Praha

Pouba Z (1966) Geologické problémy svrchního zemského pláště (Geological problems of the upper mantle). Čas. Min. Geol., 11, 353-361. Praha

Pouba Z in Sattran V et al. (1966) Problémy metalogeneze Českého masívu (Problems of metallogeny of the Bohemian Massif). Sbor. geol. Věd, Ložisk. Geol. Mineral., 8, 7-112. Praha

PoubA Z (1967) Distribution of ore minerals in the contact zones of basic intrusives. Applied Earth Science, Trans. Inst. Min. Metallurgy, 76, 13. London

Pouba Z in Ilavský J ET AL. (1967) Metallogenetic map of Czechoslovakia 1:1000 000. Ústř. Úst. geol. Praha

Pouba Z In KRUŤA T ET AL. (1967) Die Mineralienparagenese in dem mittleren Teile des Altvatergebirges (Hrubý Jeseník, Hohes Gesenke, ČSSR) I. Čas. Morav. Mus., 52, 5-28. Brno

PouBA Z IN Mísař Z (1967) Geology of the eastern marginal area of the Bohemian Massif. Guide to excursion 9AC, Int. Geol. Congr., Session 23, 1-42. Praha

Gruszczyk H, Pouba Z (1967) Stratiform ore deposits of the Bohemian Massif and of the Silesia-Cracow area. Guide to excursion 23AC, Int. Geol. Congr., Session 23, 1-48. Praha

KuŽvart M, Pouba Z et AL. (1967) Kaolin and Clay Deposits in West Bohemia. Guide to excursion 20AC, Int. Geol. Congr., Session 23, 1-31. Praha

Pouba Z (1968) Bedingungen der Entstehung der Korundund Magnetit-Paragenese. Freiberg. Forsch. H. C 231 (Breithaupt-Kolloquium), 121-125. Leipzig

Pouba Z (1969) Beziehungen zwischen der Bruchtektonik und der Erzgängen des Böhmischen Massivs. Sbor. geol. Věd, Ložisk. Geol. Mineral., 10, 7-23. Praha 
Pouba Z (1969) The Sobotín basic complex and its metallogenesis. Acta Univ. Carol., Geol., 2, 105-117. Praha

Pouba Z (1970) Distribution of ore minerals and trace elements in the contact zones of basic intrusions. In: Symposium Problems of Hydrothermal Ore Deposition. Int. Union Geol. Sci., A, 2, 68-71. Stuttgart, Budapest

Pouba Z (1970) The depth of formation and the vertical extent of ore deposition - a review of contributed papers. In: Symposium Problems of Hydrothermal Ore Deposition. Int. Union Geol. Sci., A, 2, 147-156. Stuttgart, Budapest

PoubA Z (1970) Pre-Cambrian banded magnetite ores of the Desná Dome. Sbor. geol. Věd, Ložisk. Geol. Mineral., 12, 7-64. Praha

Pouba Z, ŠTEMPRoK M (Eds) (1970) Problems of Hydrothermal Ore Deposition. Int. Union Geol. Sci., A, 2, 1-396. Stuttgart, Budapest

Pouba Z (1971) Acid rocks at the contacts of basic and ultrabasic intrusions with biotite gneisses (Vysoký Jeseník Mts., Czechoslovakia). Acta Univ. Carol., Geol., Hejtman Vol. 1-2, 123-139. Praha

Pouba Z (1971) Relations between iron and copper-leadzinc mineralization in submarine volcanic ore deposits in the Jeseníky Mts., Czechoslovakia. Soc. Min. Geol. Japan, Spec. Issue 3, Proc. IMA-IAGOD Meetings '70, IAGOD Vol., 186-192. Tokyo

Pertold Z, Pouba Z (1974) Chemical trends and ore mineralization of the volcanic rocks of the Bohemian Massif. Problems of ore deposition. IV ${ }^{\text {th }}$ IAGOD Symposium, vol. I, 281-288. Varna

Pouba Z (1974) The function of en-echelon cracks. Sbor. geol. Věd, Geol., 26, 125-133. Praha

Pouba Z, Kužvart M (1974) Geological assumptions for developing deposits of refractory raw materials. UNIDO, 1-53. Wien

Fediuk F, Pouba Z, René M (1974) Původ křemičitých hornin Hrubého Jeseníku. Acta Univ. Carol. Geol. 3, 203-230. Praha

Fediuk F, Pouba Z et al. (1975) Kvarcity, metasilexity a metakeratofyry Zlatohorského rudního revíru. Acta Univ. Carol., Geol., 2, 185-202. Praha

Suk M, Chlupáč I, PoubA Z (1976) Regionálně geologické dělení Českého masívu. Krystalinikum a varisky postižené paleozoikum. Čas. Mineral. Geol., 21, 5-10. Praha

Kotek S, Pouba Z (1977) Fault structures of triple junction type in the Bohemian Cretaceous (the Stráž Block). Čas. Mineral. Geol., 22, 239-251. Praha

Mrázek P, Pouba Z (1977) Železo, vanadij i uran v porodach proterozoja Češskogo Massiva. In: ŠMAKIN V. M. (ed) Problémy geochimii endogennych procesov. Nauka, Sibirskoe otdelenie, 252-261. Novosibirsk

Pertold Z, Pouba Z (1979) Relation between subduction and metallogenesis. In: Mahel M, Reichwalder P (Eds)
Czechoslovak Geology and Global Tectonics. Veda, 215-233. Bratislava

Pouba Z, Sattran V (1980) Copper mineralization in the Bohemian Massif. In: JANKovič S, Sillitoe RH (Eds) European Copper Deposits, 229-236. Belgrad

Fiala J, Jelínek E, Pouba Z, Poubová M, Souček J (1980) The geochemistry of the ultrabasic rocks of the Sobotín amphibolite massif(Czechoslovakia). Neu. Jb. Mineral. Abh., 137, 257-281. Stuttgart

PoubA Z (1981) Acid volcanism and mineralization in the Cadomian and Variscan stages of the Bohemian Massif history. Geol. Zbor. Geol. Carpat., 32, 547-558. Bratislava

Pertold Z, Pouba Z (1982) Prävariszische Mineralisationen der peripheren Zone des Böhmischen Massivs (ČSSR). Z. angew. Geol., 28, 365-370. Berlin

Morávek P, Pouba Z (1984) Gold mineralization and granitoids in the Bohemian Massif (Czechoslovakia). Symposium Gold '82, Geol. Soc. of Zimbabwe, Spec. Publ. 1, Balkema 713-729. Rotterdam

PADĚra K, Pouba Z (1984) White's clinopyroxene diagram applied to the differentiation of the eclogite and granulite facies. Mineralia Slov., 16, 39-42. Bratislava

Pouba Z (1984) Chemical trends and ore mineralization of some basic complexes of the Bohemian Massif. Krystalinikum 17, 129-142. Praha

Pouba Z, PAdĚra K, Fiala J (1985) Omphacite granulite from the NE marginal area of the Bohemian Massif (Rychleby Mts). N. Jb. Mineral. Abh. 151, 29-52. Stuttgart

PAdĚRA K, Pouba Z (1985) Retrográdní metamorfóza granulitů Rychlebských hor. Acta Univ. Palackianae, 83, 23-34. Olomouc

Pouba Z, Zoubek V (1985) Precambrian Metallogeny of Central Europe. International Conference on Metallogenesis of the Precambrian in Europe, IGCP Project 91, 7-57. Czech Geol. Survey. Prague

Morávek P, Pouba Z (1986) Prevariscan source of Variscan gold deposits of the Bohemian Massif. Proc. Conf. Metallogeny of the Precambrian, 65-72. Geol. Surv. Prague

Pouba Z, Ǩ̌́íbek B (1986) Organic matter and the concentration of metals in Precambrian stratiform deposits of the Bohemian Massif. Precambr. Res., 33, 225-237. Amsterdam

Pouba Z, Ilavský J (1986) Czechoslovakia. In: Dunning F M, Evans AM (Eds) Mineral deposits of Europe. Vol. 3: Central Europe. The Inst. of Mining and Metallurgy and The Mineral Soc., 117-173. London

Bernard J H, Pouba Z et al. (1986) Rudní ložiska a metalogeneze československé části Českého masívu. Ústřr. Úst. Geol., Academia, 1-320. Praha

Morávek P, Pouba Z (1987) Precambrian and Phanerozoic history of gold mineralization in the Bohemian Massif. Econ. Geol. 82, 2098-2114 
Pouba Z, Fiala J, Paděra K (1987) Granulitové těleso u Běstviny v Železných horách. Čas. Mineral. Geol., 32, 73-78. Praha

Pouba Z (1988) Silesicum. In: Zoubek V et Al. (Eds) Precambrian in Younger Fold Belts, 280-286. John Wiley and Sons. Chichester

Pouba Z (1988) Chrom, nikl a kobalt v hlubinných horninách Českého masívu. Acta Univ. Carol., Geol., 4, 481-512. Praha

Pouba Z (1990) Vertical distribution of heavy metals in the rock units of the Bohemian Massif (Central Europe). Studies in Earth Sciences, C. Naganna Felicitation Vol., 1-6. Bangalore

Moráver P, Pouba Z (1990) L'or dans la métallogenie du massif de Boheme. Mineral. Depos. 25 (Suppl.), 90-98

Zoubek V, Dudek A, Pouba Z (1992) Present views on the Pre-Variscan and Variscan history of the Bohemian Massif. In: Proceedings of the $1^{\text {st }}$ Internat. Conference on the Bohemian Massif (Z. Kukal ed.), 354-357. Czech Geol. Survey, Prague

Kříbek B, Holubář V, Parnell J, Pouba Z, Hladíková J (1993) Interpretation of thermal mesophase in vanadiferous bitumens from Upper Proterozoic lava flows (Mitov, Czechoslovakia). In: Parnell J, Kucha H And Landais P Bitumens in ore deposits, Soc. Geology Applied Mineral Deposits Spec. Publ. 9, 61-67. Springer Verlag

Pouba Z, VANĚČEK M (1994) Mineral Deposits of Eurasia.
In: VANĚČEK M (ed) Mineral Deposits of the World, 44-241. Academia. Praha

Pouba Z (1994) Mineral Deposits of South America. In: VANĚČEK M (ed) Mineral Deposits of the World, 261-294. Academia. Praha

Mísař Z, Patočka F, Pouba Z (1994) Main features of the metallogenetic development of continents and oceans. In: VANĚČEK M (ed) Mineral Deposits of the World, 384- 426. Academia. Praha

Johan Z, Johan V, Scharm B, Pouba Z (1995) Minéralogie et géochimie des terres rares et du chrome dans les cherts protérozoíques de Kokšín, Républic Tchéque. C. R. Acad. Sci. Paris, 321, Série IIA, 1127-1 138

SkočEk V, Pouba Z (2000) Neoproterozoic sedimentary carbonates and their silicified equivalents; Barrandian, Czech Republic. Bull. Czech Geol. Survey, 75, 241-260. Praha

Kř́íbek B, Pouba Z, Skoček V, Waldhausrová J (2000) Neoproterozoic of the Teplá-Barrandian Unit as a part of the Cadomian orogenic belt: a review and correlation aspects. Bull. Czech Geol. Survey, 75, 175-196. Praha

Drábek M, Pouba Z (2000) Geochemistry of Neoproterozoic calcareous rocks from the Barrandian (Czech Republic). Bull. Czech Geol. Survey, 75, 265-270. Praha Pouba Z, KŘíBek B, Pudilová M (2000) Stromatolite-like cherts in the Barrandian Upper Proterozoic: a review. Bull. Czech Geol. Survey, 75, 285-296. Praha 